590.5

FI

V. 10:2-16

v. 12:1-8

v. $14: 4$

cop. 2

INC. 


\section{CENTRAL CIRCULATION BOOKSTACKS}

The person charging this material is responsible for its return to the library from which it was borrowed on or before the Latest Date stamped below.

Theft, mutllation, and underlining of books are reasons for dlsclplinary action and may result In dismissal from
the Universlty.

TO RENEW CALL TELEPHONE CENTER, 333-8400

UNIVERSITY OF ILIINOIS LIBRARY AT URBANA-CHAMPAIGN

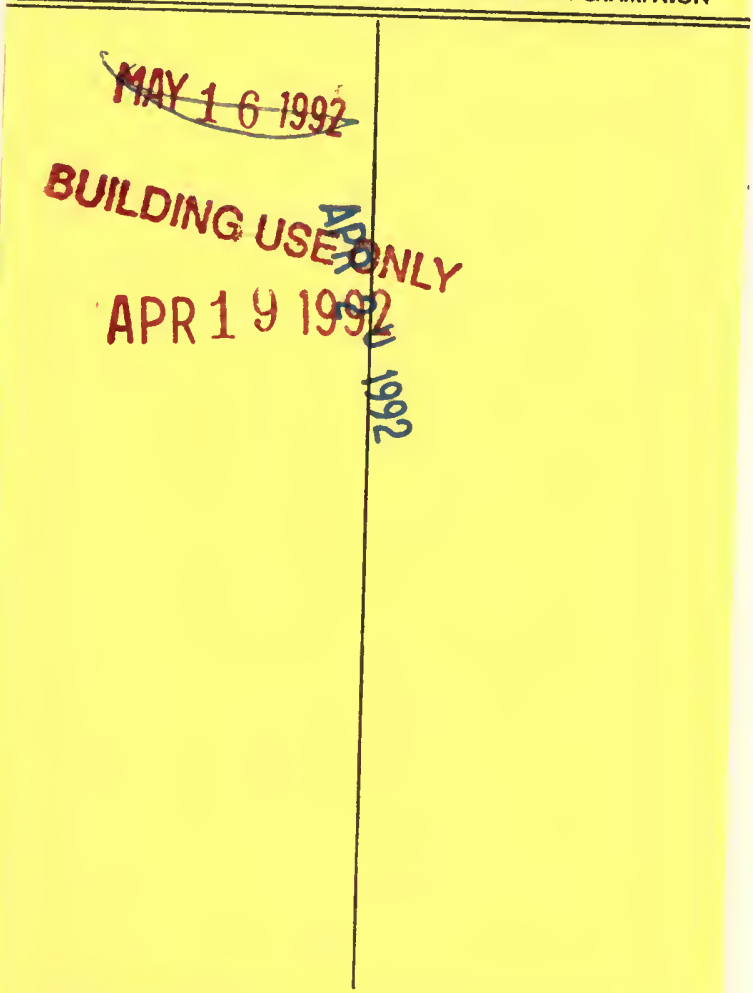

When renewing by phone, write new due date below previous due date.

79521 L162 


Field Museum of Natural History

\title{
Publication 228
}

Zoological Series

Vol. XII, No. 8

\section{TWO NEW BIRDS FROM PERU}

\author{
BY \\ JoHn T. Zimmer \\ Assistant Curator of Birds
}

REPORTS ON RESULTS OF

THE CAPTAIN MARSHALL FIELD EXPEDITIONS

Wilfred H. OsGood

Curator, Department of Zoology

EDITOR

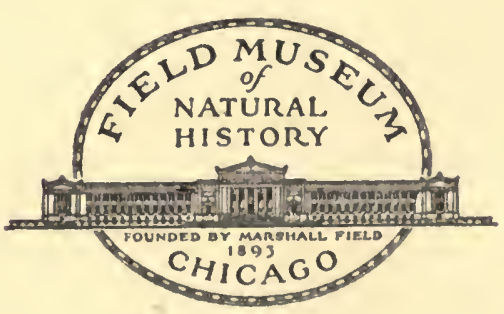

Chicago, U. S. A.

May 20, 1925 



\title{
TWO NEW BIRDS FROM PERU
}

\author{
BY JOHN T. ZIMMER
}

Further. study of the birds secured by the Captain Marshall Field Peruvian Expedition of $1922^{1}$ has resulted in the discovery of two additional new subspecies. Since a final report on the collection is still in abeyance, it seems desirable to describe the new forms in advance. Grateful acknowledgement is due to the American Museum of Natural History of New York and the Museum of Comparative Zoology of Cambridge for the loan of specimens which proved of service in determining the relationships of the species. The types of the new forms are in Field Museum of Natural History, Chicago, as are all other specimens not otherwise accredited. The names of colors when capitalized indicate direct comparison with Ridgway's "Color Standards and Color Nomenclature."

Synallaxis azarae infumata subsp. nov.

Type from Chinchao, Province of Huanuco, Peru. Altitude 5,700 feet. No. 54I57 Field Museum of Natural History. Adult male. Collected November 8, 1922 by J. T. Zimmer; original number 3203 .

Diagnosis. Closely allied to typical $S$. a. azarae from Bolivia but darker above, more grayish on the back, the crown deeper in tone and the forehead darker gray, with the frontal band much wider (9.5-II mm., av. 9.8 as against 6-7 mm., av. 6.6). The sides of the head and the superciliary line are darker gray, the latter without any white except on the supra-loral region where it is present although somewhat obscured by dusky tips to the feathers. The wing-patch appears to be paler than the crown. Beneath, the color is about as in azarae, possibly a little darker gray on the breast and with less pure white on the abdomen. The throat has the white tips to the feathers less pronounced, leaving the black bases more exposed, but this may be due to greater abrasion in the specimens examined. The shafts of the middle rectrices are somewhat blacker than in azarae. The best characters appear to

${ }^{1}$ The first preliminary report on this collection was published in Field Museum of Natural History Publication 218, Zool. Series, Vol. XII, No. 4, pp. 48-67, April 19, 1924. 
be the broader, darker frontal band, the lack of white on the superciliary stripe and the paler wing-patch. Compared with S. a. fruticicola from Ecuador, the colors are very much darker, the superciliary stripe is gray instead of buff, and the frontal band is distinctly wider (being 5-7 mm., av. 5.9 in fruticicola). Compared with S. a. elegantior from eastern Colombia and Venezuela, the differences are about as with fruticicola but the frontal band is not so much wider in proportion (being 7-9 mm., av. 8 in elegantior). From S. a. media of southwestern Colombia, the present race is separable by being decidedly darker throughout, with the chin and throat less white, the breast deeper gray without buffy tinge, the flanks olive instead of buff, the belly gray instead of white, the forehead sooty without olivaceous tinge, the crown deeper rufous, the lores, superciliary stripe and sides of head darker, etc., but the frontal band has about the same width (being 8-12 mm., av. 9.8 in media).

Habitat. Tropical and subtropical valleys of central-northern Peru.

Description of type. Forehead between Dark Olive Gray and Iron Gray, forming a band extending posteriorly to the middle of the orbit (about $9.5 \mathrm{~mm}$. from the exposed base of culmen). Crown and nape bright Auburn. Upper back Brownish Olive; rump and upper tailcoverts slightly clearer olivaceous. Chin and throat feathers black at bases, tipped with white, leaving considerable black exposed. Lores dull, dark gray mixed with white. A broad superciliary stripe the color of the forehead. Auriculars and sides of head and neck between Deep Neutral Gray and Iron Gray. Breast Neutral Gray, darker on the sides, passing into Brownish Olive on the lower flanks. Center of abdomen Pallid Neutral Gray. Under tail-coverts Light Grayish Olive. Wings dark Fuscous; remiges edged with bright Auburn except at their tips; tips of the scapulars and all of the upper wing-coverts (at least on exposed portions) pale Amber Brown, distinctly lighter in color than the crown; under. wing-coverts Ochraceous Buff; inner margins of remiges Vinaceous Fawn. Rectrices eight, in color between Auburn and Hazel, shaded with olivaceous at the base and on the outer webs and with shafts Blackish Brown; the outermost pair dusky olive without rufous tinge; tail graduated, the outermost rectrices a little longer than the under tail-coverts; feather's acute. Iris chestnut; maxilla black; mandible Slate Color; feet about Jade Green. Wing $60 \mathrm{~mm}$. ; tail IO3; culmen from base 15.5 , exposed I 2 ; tarsus 21.5 ; width of frontal band 9.5 .

Female: Like the male. 
A female from Molinopampa, Peru, is not typical but seems to be closer to this form than to fruticicola, its next nearest geographic affinity. It is slightly paler than typical infumata, with an ochreous wash on back, breast and flanks, but is darker than fruticicola. The frontal band is narrower than in infumata but broader than in fruticicola. As a matter of fact, the approach is rather toward typical azarae than toward fruticicola but the distribution of the various races does not indicate such a relationship. Although no definite characters can be found to favor the assumption, the specimen has an indefinable appearance of immaturity and the differences from typical infumata may be due to this cause.

The study of this new race has revealed a curious and interesting feature in the development of the tail. The type specimen has, distinctly, only eight rectrices, the outermost of which are just longer than the under tail-coverts, firmly webbed and colored unlike the remaining rectrices, being olivaceous without rufescence. A second male (from Huachipa) is exactly like the type in this respect. A third male (from Vista Alegre) also has only eight rectrices, but the outermost are distinctly longer than the under tail-coverts and proportionately longer than in the type. In addition, on each side, an upper tail-covert arising just above and beyond the outer rectrix, in close proximity to it, is bent downward and inward so as to occupy the position of a fifth outer rectrix, although it retains the form, size, and somewhat decomposed texture of an upper, tail-covert. A female topotype demonstrates a condition somewhat farther advanced ${ }^{1}$ in which the supernumerary feather has more definitely assumed the role of outer rectrix. This feather has become more compact or firmly webbed and is flattened, and when it is pushed around the tail to the upper surface it looks distinctly out of place. It is not noticeably stiffened and its point of origin is still slightly above the line of the adjacent rectrices. The fourth rectrix, in its turn, has lengthened considerably and assumed a suggestion of rufescent tinge, although it is still distinguishable in color from the rest of the tail. The atypical female from Molinopampa presents a still more advanced stage in the metamorphosis. The supernumerary feather has here become slightly stiffened and projects just

'I have used the term "advanced" merely as a means of describing the differences that exist and not as an indication of the actual direction of development. There is nothing to show whether the eight-feathered forms have developed from the ten-feathered or the reverse. As to whether the eight-feathered tail is more advanced or more primitive than the ten-feathered one, that with the smallest number of rectrices should probably be considered the most highly developed. 
beyond the under tail coverts as does the fourth rectrix in the type, while the fourth quill in turn extends beyond the outstretched feet of the bird. The latter is colored more, like the remainder of the tail while the fifth quill (as it has undoubtedly become) is still unlike the others although it arises directly in line with the adjacent rectrices.

In a large series of $S$. a. elegantior, only one specimen, a male from Conejos, Venezuela, exhibits but eight rectrices; the remainder show ten with the outermost on each side short, concealed by the under tailcoverts and colored like the upper tail-coverts whose structure they share except for their more stiffened and enlarged shafts. One specimen of fruticicola and two specimens of media, examined in this regard, show ten rectrices with the outermost rather more developed than in any of the elegantior.

$S$. f. frontalis, of which five males and six females were examined, appears to be separable from the entire azarae group by the character of the outermost rectrices. There are ten rectrices, and the outermost are unquestionably definable as such, and can not be confused with the tail-coverts. They are much longer than the under tail-coverts, their shafts are heavy at the base and much stiffened, and their webs are firm, while their color is identical with that of the other rectrices, being rufescent without an olivaceous tint. Two males of $S . f$. juae, including the type, agree with typical frontalis in this particular.

On the other hand, a female of $S$. superciliosa appears to have but eight tail-feathers, although the tail, being in molt, is difficult to examine with precision. The genotype, $S$. ruficapilla, in three specimens examined, also has only eight rectrices, with the outermost hardly more than modified tail-coverts as in the type of $S . a$. infumata. Bertoni in describing his new subgenus Barnesia ${ }^{1}$ with the type $S$. cururuvi (=ruficapilla), apparently confused these outer rectrices with the tailcoverts since he particularly noted that the species had only six tailfeathers. Presumably, a later examination showed him the real nature of the feathers since, in a subsequent publication ${ }^{2}$, he announced that Barnesia had eight rectrices. In any case it is evident that the genotype of Synallaxis has but eight rectrices while certain allied species have ten. Generic separation of two groups on this basis is rendered impossible by the present new subspecies, S. a. infumata, possessing a definitely intermediate structure. Dr. Hellmayr advises me, furthermore, that out of seventy-four specimens of $S$. unirufa castanea ex-

${ }^{3}$ Aves Nuevas del Paraguay, p. 77, 1901.

'Fauna Paraguaya, p. 52, footn. (3), 1914. 
amined by him, seventy-two had eight rectrices and two had ten. It is entirely possible that a critical study of other species may show a transition toward the existence of twelve rectrices in place of ten, although I have seen no tendency in that direction in any of the material I have handled.

Specimens examined:

S. a. azarae-Bolivia: Incachaca $2 \hat{\delta} 2$ qa $^{\mathrm{a}}$ Peru: Santo Domingo $6 \hat{o}$.

S. a. elegantior-Colombia: (Bogota) I $q$; Chipaque $2 \hat{o} \mathrm{I}$ 으, Choachi 1 ?a; Paramo de Tama $2 \hat{o}$. Venezuela: Conejos

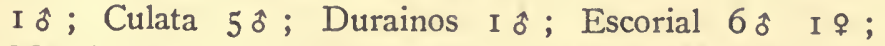
Mechisera $3 \hat{\delta}$; Nevados $2 \hat{\delta}$; Sierra de Merida I $q$; Valle 3 ô.

S. a. fruticicola-Ecuador: Alamor $2 \hat{\delta}^{\mathrm{a}}$; Celica $2 \hat{\delta}$ I $q^{\mathrm{a}}$; Guayinche I $q^{a}$; Hoyaucshi $I q$; Loja I. $\delta$; Naranjo I $q^{a}$; Salvias I $\delta^{a}$; Zaruma I $\delta$ i $q$ I? .

S. a. infumata-Peru: Chinchao I $\hat{\delta}$ (Type) 2 \% ; Huachipa I $\hat{o}$; Molinopampa (atypical) I $q$; Vista Alegre I $\hat{o}$.

S. a. media-Colombia: El Eden I ${ }^{\text {a }}$; Laguneta $2{ }^{a}{ }^{\text {a }}$; Salento I $q^{a}$; Valle de las Papas, Huila i $\hat{o}^{\mathrm{a}}$.

S. f. frontalis-Argentina: Ocampo I ô; Sarmiento I $\hat{o}$. Brazil: Chapada, Matto Grosso I $q$; Macaco Secco $2 \hat{\delta} 3$ 우 ; São Marcello I $q$; Serro Baturitè I $\delta$ I $q$.

S. f. juae-Brazil: Jua $2 \hat{o}$ (incl. Type).

S. ruficapilla-Brazil: Macieiras I $\hat{o}^{\mathrm{a}}$; Monte Serrat I ${ }^{\mathrm{a}}{ }^{\mathrm{a}}$; Ypiranga, São Paulo I ?.

S. superciliosa-Argentina: San Pablo I $q$ a.

Cyclarhis gujanensis saturatus subsp. nov.

Type from Cullcui, Marañon River, Peru. Altitude Io,400 feet. No. 54106 Field Museum of Natural History. Adult male. Collected December I3, I922 by J. T. Zimmer; original number 3300 .

Diagnosis. Similar to C. g. contrerasi but somewhat larger and richer in tone of coloration. The throat, breast and sides of the face are deeper yellow and the color spreads farther posteriorly over the breast where it is distinctly tinged with olive, especially on the sides.

a. Specimens in American Museum of Natural History, New York. 
The chin is narrowly white; the flanks and abdomen are strongly suffused with deep ochraceous except on the middle of the latter where the color is soiled white. The back is darker green than in contrerasi and the chestnut of the crown extends farther backwards over the nape.

Habitat. Temperate valley of the upper Marañon River, northcentral Peru.

Description of type. Center of crown and occiput Serpentine Green, the feathers margined and tipped with Auburn; the rest of the entire top of the head and neck Auburn, becoming paler, approaching Sanford's Brown, on the nape; a narrow line of Auburn continued beneath entirely around the orbit; lores, except for the circumocular line, paler, ochraceous. There is a short but distinct line of pale brown extending posteriorly from the base of the mandibular ramus and separating a small whitish malar spot from the whitish chin. Throat, auriculars and sides of the neck are rich golden yellow, nearest Lemon Chrome, passing into Pyrite Yellow on the sides and approaching that hue in the center of the breast; the color extended broadly posteriorly. Flanks rich Cinnamon Buff; abdomen and under tail-coverts somewhat paler, the upper abdomen whitish in the middle. Back Warbler Green; rump slightly paler. Exposed webs of upper. wing-coverts like the back; concealed portions blackish. Primaries and secondaries with exposed outer webs slightly paler than the back; inner margins of inner webs Pale Lemon Yellow. Tertials like the back but duller. Under wing-coverts Pale Lemon Yellow; axillaries between Lemon Yellow and Lemon Chrome. Iris Empire Yellow; maxilla Verona Brown; mandible Dark Green-Blue Slate, tip whitish; legs and feet near Light Vinaceous Cinnamon. Wing $86 \mathrm{~mm}$; t tail 72 ; culmen to base 20 , exposed 17 ; tarsus 26.

Adult female: Like the male.

Immature female: Distinguishable from the adults of both sexes by having the auburn on the top of the head restricted to the forehead and the lateral portions where it forms a broad superciliary stripe, leaving the center of the crown, occiput and nape uniform with the back, without rufous margins. The rectrices are narrower toward the tips and more sharply pointed than in the adults, and the bill, in the specimen examined, is somewhat less hooked at the tip.

Like $C . g$. contrerasi, this subspecies (in the adult plumage) is distinguishable from $C . g$. virenticeps by having the green of the crown restricted to the discs of the feathers. In the immature plumage this 
difference is not apparent, but the immaturity of a specimen and its consequent value for comparison may be determined by the condition of the tips of the rectrices ${ }^{1}$.

I am disposed to place the present form, together with contrerasi and virenticeps, under $C$. gujanensis, hitherto considered to be a distinct species, on the evidence exhibited by a specimen of contrerasi in the Museum of Comparative Zoology (No. 79898), taken at Huancabamba, Peru. In this example, the fore part of the crown is decidedly grayish although there are fine rufous edges to the feathers, the nape is tinged with gray, the fore part of the auriculars is gray and the yellow chest-band is quite narrow. The specimen seems to represent a distinct transition between contrerasi and gujanensis, both of which occur in northern Peru, the former toward the west and the latter toward the east.

Specimens examined:

C. g. contrerasi-Ecuador: Loja I ồ ${ }^{\text {. }}$. Peru: Huancabamba $2 q^{\mathrm{b}}$; Perico I क $^{\mathrm{b}}$; Tabaconas $\mathrm{I}$ \% $\mathrm{imm} .^{\mathrm{b}}$.

C. g. gujanensis-Brazil: Manaos I 9 .

C. g. saturatus-Peru: Cullcui, Marañon River $I \hat{o}$ (Type) I 9 ad. I i $\mathrm{imm}$.

C. g. virenticeps-Ecuador: Chone $2 \hat{\delta}^{\mathrm{a}}$; Guayaquil $2 q^{\mathrm{a}}$; Zaruma $I$ 우․

${ }^{1}$ The specimen recorded by Bangs and Noble (Auk, 35, p. 458, Oct. 1918) as virenticeps from Tabaconas, Peru, proves, on examination, to be an immature contrerasi. The tips of the rectrices are narrowed toward the tip and narrowly pointed and the lower mandible is just beginning to assume the slaty blue color at the base as found in the adults.

a. Specimens in the American Museum of Natural History, New York.

b. Specimens in the Museum of Comparative Zoology, Cambridge. 





|

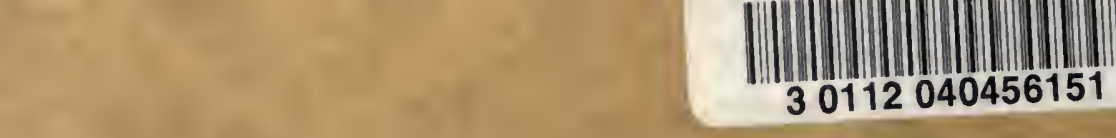

\author{
I
}

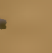

\title{
${ }_{30112040456151}$
}

(1) 